\title{
Factors related to hemodialysis safety culture: integrative literature review
}

\author{
Fatores relacionados à cultura de segurança em hemodiálise: revisão integrativa da literatura \\ Factores relacionados con la cultura de seguridad en hemodiálisis: revisión de literatura integradora
}

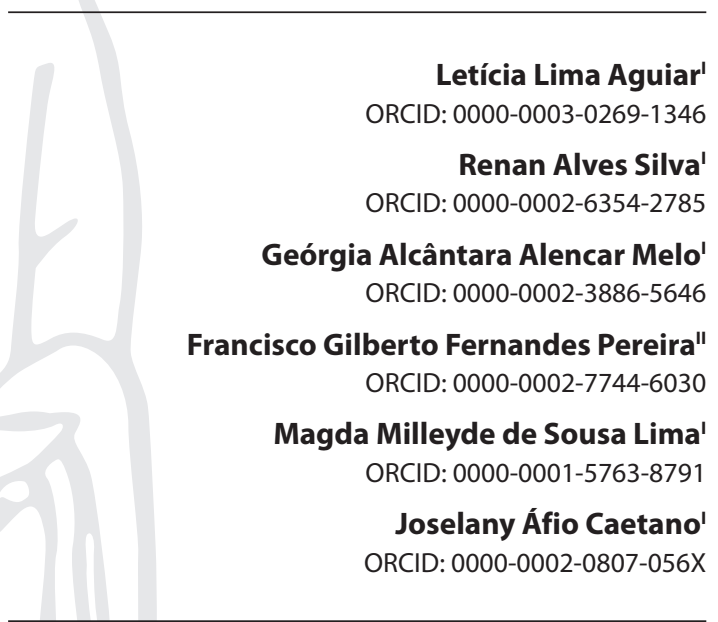

'Universidade Federal do Ceará. Fortaleza, Ceará, Brazil. "Universidade Estadual do Ceará. Fortaleza, Ceará, Brazil.

How to cite this article:

Aguiar LL, Silva RA, Melo GAA, Pereira FGF, Lima MMS, Caetano JA. Factors related to hemodialysis safety culture: integrative literature review. Rev Bras Enferm. 2020;73(6):e20190624. doi: http://dx.doi.org/10.1590/0034-7167-2019-0624

\section{Corresponding author:} Letícia Lima Aguiar E-mail: leticiaaguiar1991@hotmail.com

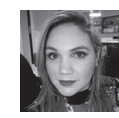

EDITOR IN CHIEF: Antonio José de Almeida Filho ASSOCIATE EDITOR: Hugo Fernandes

Submission: 11-29-2019 Approval: 02-05-2020

\begin{abstract}
Objective: To analyze the factors involved in nursing care that are related to the safety culture of chronic renal patients on hemodialysis. Method: Integrative literature review, carried out through the steps: problem identification, bibliographic research, data evaluation, data analysis, and report. We adopted the guiding question: "What scientific evidence is there about the factors related to the safety culture in hemodialysis clinics, according to the nursing team?"The search was carried out in the LILACS, Medline / PUBMED, Scopus, CINAHL, Cochrane, and Web of Science (WOS) databases. Results: The sample of this review was composed of five studies. The factors found were: 8 predisposing, 13 disabling, 11 precipitating, and 18 reinforcing. Conclusion: The analysis of literary productions allowed an understanding of the main factors linked to nursing practices that influence the safety culture of patients on hemodialysis.

Descriptors: Nephrology Nursing; Patient Safety; Hemodialysis Units, Hospital; Nursing Care; Precipitating Factors.
\end{abstract}

\section{RESUMO}

Objetivo: Analisar os fatores envolvidos na assistência de enfermagem que estão relacionados à cultura de segurança de pacientes renais crônicos em tratamento hemodialítico. Método: Revisão integrativa da literatura, realizada mediante as etapas: identificação do problema, pesquisa bibliográfica, avaliação dos dados, análise dos dados e relatório. Adotou-se a questão norteadora: "Quais evidências científicas existem sobre os fatores relacionados à cultura de segurança em clínicas de hemodiálise, segundo a equipe de enfermagem?" A busca foi realizada nas bases de dados LILACS, Medline/PUBMED, Scopus, CINAHL, Cochrane e Web of Science (WOS). Resultados: A amostra desta revisão foi composta por cinco estudos. Os fatores encontrados foram: 8 predisponentes, 13 incapacitantes, 11 precipitantes e 18 reforçadores. Conclusão: A análise das produções literárias permitiu compreensão dos principais fatores ligados às condutas de enfermagem que influenciam na cultura de segurança do paciente em tratamento hemodialítico.

Descritores: Enfermagem em Nefrologia; Segurança do Paciente; Unidades Hospitalares de Hemodiálise; Cuidados de Enfermagem; Fatores Desencadeantes.

\section{RESUMEN}

Objetivo: Analizar los factores envueltos en la asistencia de enfermaría que están relacionados a la cultura de seguridad de pacientes renales crónicos en tratamiento hemodialítico. Método: Revisión integrativa de la literatura, realizada mediante las etapas: identificación del problema, investigación bibliográfica, evaluación de los datos, análisis de los datos e informe. Se ha optado la cuestión orientadora: "¿Cuales evidencias científicas existentes sobre los factores relacionados a la cultura de seguridad en clínicas de hemodiálisis, segundo el equipo de enfermaría?" La búsqueda ha sido realizada en las bases de datos LILACS, Medline/ PUBMED, Scopus, CINAHL, Cochrane y Web of Science (WOS). Resultados: La muestra de esta revisión ha sido compuesta por cinco estudios. Los factores encontrados han sido: 8 predisponentes, 13 discapacidades, 11 precipitantes y 18 reforzadores. Conclusión: El análisis de las producciones literarias ha permitido comprensión de los principales factores relacionados a las conductas de enfermaría que influencian en la cultura de seguridad del paciente en tratamiento hemodialítico.

Descriptores: Enfermaría en Nefrología; Seguridad del Paciente; Unidades Hospitalarias de Hemodiálisis; Cuidados de Enfermaría; Factores Desencadenantes. 


\section{INTRODUCTION}

In the last decades, patient safety has become a worldwide concern of health service organizations, as it is considered an essential factor for the quality of care through safe and harmfree care $^{(1)}$.

In this context, aiming to mitigating the damage arising from inadequate practices in care services, some strategies have been instituted, of which the creation of the Programa Nacional de Segurança do Paciente (PNSP- National Patient Safety Program ), through Ordinance No. 529/2013, of Ministério da Saúde (Health department), which aims to promote the implementation of actions aimed at patient safety ${ }^{(2)}$. Some factors hinder the implementation of these strategies, namely: reduced number of professionals in the nursing team, lack of support from senior management, and lack of adherence by healthcare professionals ${ }^{(3)}$.

The importance of the topic of safety in the different areas of assistance is noteworthy, for example, that of hemodialysis, due to the high number of patients with chronic kidney disease and the probability of incidents related to the assistance provided $^{(2,4)}$. Hemodialysis is a complex procedure, which provides a higher risk to the patient, with an average of $2 \%$ to $4 \%$ of deaths ${ }^{(5)}$.

In Brazil, in 2016, the percentage of dialysis patients hospitalized per month was $5.2 \%$, and the annual number of dialysis patients who died was $22,337^{(6)}$. A study analyzed the medical records of 117 patients in the hemodialysis unit and evidenced the prevalence of $80.3 \%$ of adverse events (AE). Inadequate blood flow was the most prevalent $A E$, with the majority of the damage being classified as mild; what justified this value were aspects related to treatment, due to the use of high technology equipment, such as the hemodialysis machine; need for a multidisciplinary team; invasive procedures; administration of potentially dangerous drugs (PDD); and patient turnover ${ }^{(7)}$.

Also, for there to be safety in the treatment of hemodialysis, the nursing staff must be concerned about accessing the bloodstream through an arteriovenous fistula or central access, connecting the dialysis lines, monitoring the patient for complications and hemodynamic stability ${ }^{(8)}$.

Therefore, the high prevalence of AE in hemodialysis has a connection with factors related to the care processes, as well as to the institution's safety culture. Such factors can be: predisposing, that is, those that lead to an increase in susceptibility to the event; disabling factors, which interfere with insecurity or the promotion of a safety culture; precipitating factors, which start the causal chain; and reinforcing factors, which amplify the effect of an existing clinical condition ${ }^{(9)}$.

These reasons are rooted in complications arising from kidney disease itself, in pre-existing clinical conditions, in the nature of care offered by the health team, and in other peculiarities related to the safety culture promoted by the institution.

In this sense, to reduce the chances and effects of adverse events, it is essential to establish the predisposing, disabling, precipitating and reinforcing factors of the safety culture present in nursing care, in order to understand the aspects that are related to the safety culture of chronic renal patients on hemodialysis.

\section{OBJECTIVE}

To analyze the factors involved in nursing care that are related to the safety culture of chronic renal patients on hemodialysis.

\section{METHOD}

\section{Study design}

An integrative literature review, a method that allows investigation of previous research, systematically and comprehensively, to generate knowledge and identify gaps for the scientific community ${ }^{(10)}$. In order for research to have scientific contributions to clinical practice, it is necessary to use methodological criteria. In this context, the present study followed the steps: identification of the problem (formulation of the question), bibliographic research, data evaluation, data analysis, and report ${ }^{(11)}$.

\section{Data collection period}

The survey was conducted between November and December 2017.

\section{Inclusion and exclusion criteria}

The established inclusion criteria were: article published in English, Portuguese, or Spanish; address the factors involved in nursing care related to the safety culture of renal patients on hemodialysis, without temporal delimitation. Exclusion criteria: case or experience reports; reviews; articles that were not directly related to the topic or that addressed patient safety in other types of dialysis therapies, such as kidney transplantation and peritoneal dialysis, and that did not bring nursing care in the context of the safety culture. Duplicate articles were excluded.

\section{Study Protocol}

The formulation of the question was inspired by the PVO strategy $(\mathrm{P}=$ population, $\mathrm{V}=$ variables, and $\mathrm{O}=$ outcomes $)$, which is an adaptation of the PICO strategy (Patient, Intervention, Comparison, and Outcomes) ${ }^{(12)}$, defining as Population - nursing professionals; Variables - factors related to safety culture in hemodialysis clinics; Outcome - safety of renal patients on hemodialysis.

The guiding question was adopted to identify the problem: "What scientific evidence is there about the factors related to the safety culture in hemodialysis clinics, according to the nursing team?"

The databases for mobilizing primary sources were selected: LILACS (Latin American and Caribbean Health Sciences Literature), Medline / PUBMED (National Library of Medicine and National Institutes of Health), Scopus, CINAHL (Cumulative Index of Nursing and Allied Health Literature), Cochrane, Web of Science (WOS).

First, from the question and the research objectives, the keywords were obtained and translated into documentary language or descriptors based on the Descritores em Ciências da Saúde (DeCS-Health Sciences Descriptors ) and Medical Subject Headings (Mesh). Ee selected the terms Patient Safety, Nephrology Nursing, and Renal Dialysis as root or primary descriptors, and 
the combination was established with the Boolean operators: "Patient safety" AND "Nephrology Nursing" AND "Renal dialysis." We carried out the second search in order to complete the selection of articles. For that, some citations used by authors of the selected studies that were relevant to the present study were located and incorporated.

Peer research was carried out, which also involved the final decision to include or exclude studies. Six studies were identified in Medline / PUBMED, 50 in Scopus, and 83 in CINAHL, totaling 139 studies in primary research. Among them, seven were duplicated, and 107 studies were eliminated because they did not focus on the safety culture, but safety in the development of new drugs and devices; because they were summaries presented at conferences, or editorials and a letter to the president of the Association of North American Nephrologist Nurses; and because they only address peritoneal dialysis.

\section{Results analysis and statistics}

In evaluating the data, we verified whether the article included nursing care that influenced the patient's safety culture. Therefore, we eliminated studies that discussed the nurses' perception of safety culture or patients facing safety-e.g., puncture technique, use of devices, water treatment, and quality parameters inherent to HD treatment -, but that did not focus on nursing care or safety as a broad concept. Four studies were excluded because they were reviews, one being integrative, and three narratives. The selection and eligibility process of the studies followed the recommendations of PRISMA 10, shown in Figure 1.

The researchers constructed an instrument to extract the data, which included: study title, authorship, journal, year of publication, study location (country), research objective(s), methodological details, main results and conclusions found. The presentation of the results was organized in a framework of characterization of the studies, which contain authors/year, main objective, and results.

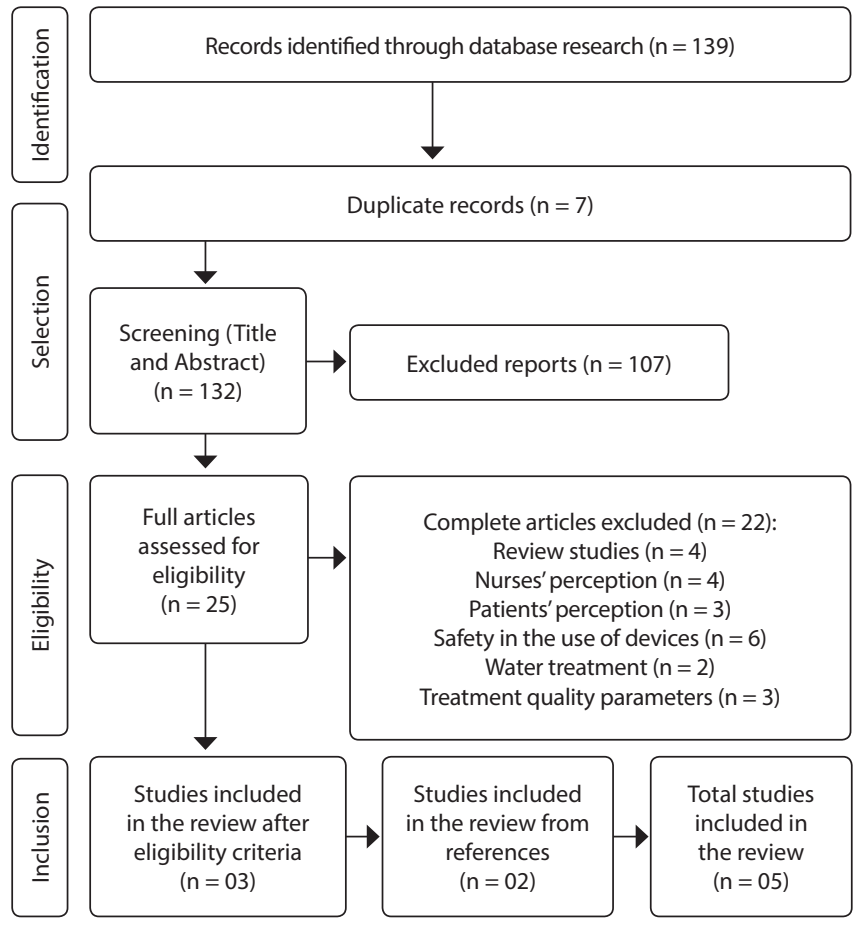

Figure 1 - Flowchart of the process of identification, selection, and inclusion of studies, prepared based on the PRISMA recommendation

\section{RESULTS}

The sample of this review included five studies; of these, three (60\%) were from the United States of America (USA), and the rest were from Spain and Greece, one study from each country. As for the methodological design and database, the five were cross-sectional, being four from Scopus and one from CINAHL.

Two cross-sectional studies used a qualitative approach, with an interview about the practices and processes used to improve patient safety and quality of care in the unit, as well as to explore the manager's safety practices before, during, and after the HD procedure.

Chart 1 - Characterization data of the included articles, 2018

\begin{tabular}{|c|c|c|c|c|}
\hline Titles & $\begin{array}{c}\text { Years } \\
\text { Countries }\end{array}$ & $\begin{array}{l}\text { Designs / } \\
\text { samples }\end{array}$ & Interventions & Outcomes \\
\hline $\begin{array}{c}\text { Nurse Manager } \\
\text { Safety Practices } \\
\text { in Outpatient } \\
\text { Hemodialysis } \\
\text { Units }^{(13)}\end{array}$ & $\begin{array}{c}2015 \\
\text { US }\end{array}$ & $\begin{array}{l}\text { Cross-sectional } \\
n=422 \text { nurses }\end{array}$ & - & $\begin{array}{l}\text { The safety practices designed to reduce safety risk included: monitoring } \\
\text { patient risk behaviors, enforce security policies and procedures, provide } \\
\text { informal and formal education, manage patient flow, and involve } \\
\text { patients in their care. Some practices relevant to the nursing team were: } \\
\text { monitoring and observing staff; conduct formal audits; resolve security } \\
\text { flaws in personnel care practices; and advise, train and take disciplinary } \\
\text { action when necessary. }\end{array}$ \\
\hline $\begin{array}{l}\text { RN Staffing and } \\
\text { Workload, Dialysis } \\
\text { Work Environment, } \\
\text { Processes of Nursing } \\
\text { Care and Patient } \\
\text { Safety Culture } \\
\text { in Outpatient } \\
\text { Hemodialysis }_{\text {Facilities }}^{(14)}\end{array}$ & $\begin{array}{c}2013 \\
\text { US }\end{array}$ & $\begin{array}{l}\text { Cross-sectional } \\
n=422 \text { nurses }\end{array}$ & - & $\begin{array}{l}\text { Nurses reported at least monthly the occurrences of hypotension, } \\
\text { patients' falls in the unit, and hospitalizations. The study observed } \\
\text { significant associations between nurses' reports about patient transition } \\
\text { and the increased probability of occurrences of ignored and shortened } \\
\text { dialysis treatments; infiltration, infection, thrombosis and vascular access } \\
\text { hemorrhage; family/patient complaints; medication error and use of the } \\
\text { emergency room. There was also a significant association between the } \\
\text { negative safety scores attributed by nurses and the greater probability of } \\
\text { the occurrence of adverse events, such as inadequate staff levels, lack of } \\
\text { procedural guidance, training, patient education, or application of policies. }\end{array}$ \\
\hline
\end{tabular}


Chart 1 (concluded)

\begin{tabular}{|c|c|c|c|c|}
\hline Titles & $\begin{array}{c}\text { Years } \\
\text { Countries }\end{array}$ & $\begin{array}{l}\text { Designs / } \\
\text { samples }\end{array}$ & Interventions & Outcomes \\
\hline $\begin{array}{c}\text { The work } \\
\text { environment of } \\
\text { hemodialysis } \\
\text { nurses and their } \\
\text { impact on patients' } \\
\text { outcomes }^{(15)}\end{array}$ & $\begin{array}{c}2015 \\
\text { Greece }\end{array}$ & $\begin{array}{l}\text { Cross-sectional } \\
n=133 \text { nurses }\end{array}$ & - & $\begin{array}{l}\text { The disconnection of the venous needle from the fistula or graft was } \\
\text { statistically significant when correlated with the work environment. } \\
\text { Nurses who declared falls as frequent / very frequent scored low scores } \\
\text { for the work environment (Mean }=2.1 ; \mathrm{SD}=2.2) \text {. Medication errors were } \\
\text { reported as frequent }(8.3 \%) \text { to rare }(64.7 \%) \text {. Catheter-associated infection } \\
\text { and hypoglycemia were reported as frequent / very frequent adverse } \\
\text { events }-39.8 \% \text { and } 26.4 \% \text {, respectively. }\end{array}$ \\
\hline $\begin{array}{c}\text { Patient safety } \\
\text { culture in } \\
\text { nephrology nurse } \\
\text { practice settings: } \\
\text { Initial findings. } \\
\text { Nephrology }^{(16)}\end{array}$ & $\begin{array}{c}2014 \\
\text { US }\end{array}$ & $\begin{array}{l}\text { Cross-sectional } \\
\qquad \begin{array}{c}n=979 \\
\text { Nurses }\end{array}\end{array}$ & - & $\begin{array}{l}\text { The study noted the most common safety-related concern in the } \\
\text { underreporting of events and near misses, including lack of time, heavy } \\
\text { documentation systems, absence of managerial support or monitoring of } \\
\text { reported events, and actual or perceived punishment for the employee } \\
\text { reporting an event. Focus on productivity was mentioned, weakening } \\
\text { the focus on the patient. Nurses reported having many responsibilities } \\
\text { and little time available to care for and verify the technicians' work. } \\
\text { Events such as incorrect weights and lack of communication were also } \\
\text { mentioned. The risk of infection was largely attributed to the lack of } \\
\text { knowledge, time, and attention to protocols. }\end{array}$ \\
\hline $\begin{array}{c}\text { Relationships } \\
\text { between registered } \\
\text { nurse staffing, } \\
\text { processes of nursing } \\
\text { care, and nurse- } \\
\text { reported patient } \\
\text { outcomes in chronic } \\
\text { hemodialysis }^{\text {units(17) }}\end{array}$ & $\begin{array}{c}2008 \\
\text { US }\end{array}$ & $\begin{array}{l}\text { Cross-sectional } \\
n=422 \text { nurses }\end{array}$ & - & $\begin{array}{l}\text { the study has shown significant relationships between the occurrence of } \\
\text { adverse events, such as volume overload; pneumonia hospitalizations, } \\
\text { infection, infiltration, thrombosis, and bleeding in vascular access; fall } \\
\text { with and without injury; medication errors; hypotension, shortened and } \\
\text { ignored dialysis treatments; and patient complaints. The patient-nurse } \\
\text { ratio of } 12 \text { or more was significantly associated with a higher probability } \\
\text { of shortened dialysis times, just as patient complaints were ignored } \\
\text { compared to the proportion of } 4.61 \text { or fewer patients per nurse. }\end{array}$ \\
\hline
\end{tabular}

The studies assessed the nurses' work environment using the instruments: Practice Environment Scale of the Nursing Work Index (PES-NWI), Questionnaire on Hospitals Patient Safety Culture (HSOPSC), and Research Instrument of the Medical Office on Patient Safety Culture (MOSPSC).

Two cross-sectional studies used a qualitative approach, with an interview about the practices and processes used to improve patient safety and quality of care in the unit, as well as to explore the manager's safety practices before, during, and after the HD procedure. Chart 1 presents information regarding the title, year, country, design, sample, intervention, and outcome of the articles included in the research.

The following are the factors of nursing care related to the safety culture of the studies included in the review, according to classification: predisposing, disabling, precipitating, and reinforcing.

Table 1 - Factors related to nursing care that interfere in the safety culture of chronic renal patients on hemodialysis, 2018

$\mathbf{f}(\%)$

Predisposing factors

Fall risk reduction

The decrease in patients hospitalization rate

The nursing team focus on patients and not on machines

Do not eat during treatment

Do not allow covering the patients' faces and access devices during treatment

Event and near miss notification

Volume overload reduction

Use of personal protective equipment in patients with hepatitis B

Disabling factors

Vascular access infection $\quad 100$

Drug Errors

Hypotension

Vascular access thrombosis

Shortened dialysis times

Unexpected bleeding from vascular access

Vascular access infiltration

Failure to adhere to security procedures

Non-compliance in the waste disposal

Hypoglycemia

Failure of patients to clean their access sites before HD starts

Errors concerning dilution of the dialysis solution

Needle disconnection 
Precipitating factors

Provision of knowledge, skills, and guidance needed by the nursing team

Effective communication during patient transfers and transitions in dialysis centers

Time availability for the nursing staff

Communication between nurses

Participation of nurses in hospital management matters

Provision of management support or monitoring of a reported event

No real or perceived punishment for an employee reporting an event

Analyze patient complaints

Evaluation of vascular access before the puncture

Sensitivity to patient complexity and complications

Absence of heavy documentation systems

Reinforcing factors

Adequate staffing

Provision of security policies, procedures, and guidelines

Strong leadership practice of the nursing team

Providing patient education

Hand washing

Wearing gloves

Training of new employees

Safety assessments during the patient transition

Productive communication relationship between doctor and nurse

Implementation of measures to adjust the prescription for patient hospitalization

Proper patient flow management

Monitoring and observation of nursing care

Active devices to monitor patient safety risks

Involving patients in their care

Proper water treatment

Monitoring of patient risk behaviors

Monitoring and effective management of patients' demands to start and finish their HD treatments

Proper teamwork

\section{0}

40

20

20

20

20

20

20

20

20

\section{DISCUSSION}

The safe hemodialysis treatment is complex and multi-causal, and the nursing team should be concerned with factors related to the patient's safety culture, among which the most relevant ones are defined as predisposing, disabling, precipitating and reinforcing ${ }^{(9)}$.

The factors classified as predisposing make a phenomenon prone to happen ${ }^{(9)}$, in this case, the safety culture. In this context, we identified eight factors in the published studies, with "risk of falling reduction" being the predisposing factor, with a frequency of $100 \%$ in articles. This result is justified since chronic renal patients on hemodialysis treatment are prone to the risk of falling since the patient's balance is altered after a hemodialysis treatment session, regardless of the age group ${ }^{(18)}$.

Besides, the factors "decreased patients hospitalization rate" and "focus of the nursing team on patients and not on machines" can be highlighted, both present in $40 \%$ of the sample. They influence the patient's safety culture, because, despite the advanced technology, hemodialysis is a substitute therapy that can cause complications, due to the patients' hemodynamic instability, and the hemodialysis machine is an essential technology for the life of patients with chronic kidney disease ${ }^{(19)}$. Thus, the nursing team must present clinical knowledge to carry out systematic and planned care, focusing on the patient and independently of the care provided in the routine of the sector ${ }^{(20)}$.

Also, the studies point out the following factors: reduction in volume overload, use of personal protective equipment in patients with hepatitis B; event and near miss notification; and not allowing to cover patients' faces and access devices during treatment, in addition to not eating during treatment. All of these factors were present in $20 \%$ of the studies found in the literature.

In turn, the factor classified as disabling has a connection with situations that interfere in the event ${ }^{(9)}$. This study identified 13 situations that influence safety culture. The factor "vascular access infection" was present in $100 \%$ of the studies analyzed, given that the venous catheter is a risk factor for the development of infections, mainly when it is associated with the length of time using the device(21).

Then, there was a predominance of the factor "medication error," present in $80 \%$ of the studies. This adverse event leads to failures in prescription, dispensation, and administration. Multiprofessional work, effective communication, and the use of educational and organizational strategies are required to reduce medication errors ${ }^{(22)}$.

Another predominant factor was "hypotension", found in $60 \%$ of the analyzed articles. According to another study, carried out with chronic kidney patients, hypotension is one of the most severe complications that occur most frequently during the hemodialysis session, representing $85.7 \%$ of the cases. Intradialytic hypotension is related to filtration volume, plasma osmolality, hypovolemia, and vasodilation ${ }^{(23)}$.

A study suggests that some measures should be adopted to reduce the hypotension index during hemodialysis sessions, which include: increasing the sodium rate, reducing the dialysate temperature, and reducing ultrafiltration rates ${ }^{(24)}$.

In turn, the precipitating factors are related to the process of causation ${ }^{(9)}$. In the present study, there were 11 types of factors, with a predominance of subjects: effective communication during patient transfers and transitions in dialysis centers; and providing 
knowledge, skills, and guidance needed by the nursing team both factors were in $40 \%$ of the studies analyzed.

The following actions are emphasized to improve communication strategies: recognizing team failures, improving dialogue, holding meetings with the multiprofessional team with performance evaluation and feedback ${ }^{(25)}$.

Finally, reinforcing factors refer to situations that enhance existing situations ${ }^{(9)}$. This study identified 18 factors. The adequate staffing was the main reinforcement item, found in $80 \%$ of the studies analyzed.

These data corroborate international research carried out in 243 hospitals in Europe, which shows the correlation between the culture of patient safety and team staffing ${ }^{(26)}$. The quality and the correct number of professionals is an indispensable resource for organizing the work environment and providing effective patient care according to the patient's needs, requiring effective planning to generate safe and comprehensive care for the patient ${ }^{(27-28)}$.

Therefore, in order to organize health services, the Conselho Federal de enfermagem (Federal Nursing Council) published Resolution 0527/2016 (12) in Brazil, which establishes criteria for the staffing of nursing professionals ${ }^{(29)}$.

\section{Study Limitations}

The study had as a limitation the invisibility of nephrology nursing in Brazil and Latin America, considering that the publications found were restricted to the United States of America and Greece. Thus, in order to seek new scientific evidence, it is necessary to invest in future research on the safety culture of chronic kidney patients and the development of effective analysis tools that work with influencing factors, especially in hospital practice during hemodialysis treatment.

\section{Contributions to nursing, health, or public policy fields}

The present study demonstrated the predisposing, disabling, precipitating, and reinforcing factors related to the safety culture of patients with chronic kidney disease on hemodialysis, in order to enable nurses and health professionals to provide assistance based on the safety culture, aiming to reduce the occurrence of adverse events. Also, with the results of the study, it is possible to design effective interventions in the short and long term, to make the care safe and with lower risks to the patient in hemodialysis clinics.

\section{CONCLUSION}

The analysis of literary productions on factors related to the safety culture of patients undergoing hemodialysis allowed, above all, the establishment and division of the main predisposing, disabling, precipitating, and reinforcing factors present in nursing care.

Thus, "causal factors" were chosen as those with the most considerable risks, reported with a percentage higher than $50 \%$ in the selected productions. Thus, the "risk of falls reduction" was identified as a predisposing factor; "vascular access infections", "medication errors", "hypotension" as disabling factors; and "adequate staffing" and "providing security policies, procedures, and guidelines" as reinforcing factors of the safety culture.

With that, it becomes possible to understand the main aspects related to the usual routine behaviors that influence patient safety.

\section{REFERENCES}

1. Simam AG, Cunha SGS, Brito MJM. Nursing actions for patient safety in hospitals: integrative review. Rev Enferm UFPE. 2017 [cited 2018 Jul 10];11(Supl.2):1016-24. doi: 10.5205/reuol.10263-91568-1-RV.1102sup201718

2. Ministério da Saúde (BR). Agência Nacional de Vigilância Sanitária. Resolução n 36, de 25 de julho de 2013. Institui ações para a segurança do paciente em serviços de saúde e dá outras providências. Brasília: Ministério da Saúde; 2013.

3. Reis GAX, Oliveira JLC, Ferreira AMD, Vituri DW, Marcon SS, Matsuda LM. Dificuldades para implantar estratégias de segurança do paciente: perspectivas de enfermeiros gestores. Rev Gaúcha Enferm. 2019;40(esp):1-7. doi: 10.1590/1983-1447.2019.20180366

4. The Scottish Renal Registry. Scottish Renal Registry Annual Report 2016 [Internet]. National Services Scotland. 2016 [cited 2018 Jul 10$]$ p 107. Available from: http://www.srr.scot.nhs.uk/Publications/docs/scottish-renal-registry-report-2016-web.pdf

5. Bray BD, Boyd J, Daly C, Doyle A, Donaldson K, Fox JG, et al. How safe is renal replacement therapy? a national study of mortality and adverse events contributing to the death of renal replacement therapy recipients. Nephrol Dial Transplantation. 2013;29(3):681-7. doi: $10.1093 / \mathrm{ndt} / \mathrm{gft} 197$

6. Sociedade Brasileira de Nefrologia. SBN Informa [Internet]. 2016[cited 2018 Jul 10]. Available from: https://sbn.org.br/app/uploads/ sbninforma106_2016_site-1.pdf

7. Sousa MRG, Silva AEBC, Bezerra ALQ, Freitas JS, Neves GE, Paranaguá TTB. Prevalence of adverse events in a hemodialysis unit. Rev Enferm UERJ. 2016;24(6):e18237. doi: 10.12957/reuerj.2016.18237

8. Bray BD, Metcalfe W. Improving patient safety in haemodialysis. Clin Kidney J. 2015;8(3):262-4. doi: 10.1093/ckj/sfv033

9. Lopes MVO, Silva, VM, Herdman TH. Causation and Validation of Nursing Diagnoses: a middle range theory. Int J Nurs Knowledge, 2017;28(1):53-9. doi: 10.1111/2047-3095.12104

10. Ercole FF,Melo LS, Alcoforado CLGC. Revisão integrativa versus revisão sistemática. Rev Min Enferm. 2014;18(1):9-12. doi: 10.5935/1415-2762.20140001

11. Whittemore R, Knafl K. The integrative review: updated methodology. J Adv Nurs. 2005;52(5):546-53. doi: 10.1111/j.1365-2648.2005.03621.x 
12. Santos CMDC, Pimenta CADM, Nobre MRC. The PICO strategy for the research question construction and evidence search. Rev Latino-Am Enferm. 2007;15(3):508-11. doi: 10.1590/S0104-11692007000300023

13. Thomas-Hawkins C, Flynn L, Lindgren TG, Weaver S. Nurse Manager Safety Practices in Outpatient Hemodialysis Units. Nephrol Nurs J. 2015;42(2):125-33. doi: 10.1891/1541-6577.29.1.1

14. Thomas-Hawkins C, Flynn L. RN staffing and workload, dialysis work environment, processes of nursing care, and patient safety culture in outpatient hemodialysis facilities [Abstract], Nephrology Nurs J [Internet]. 2013[cited 2018 Jul 10];40(2):170. Available from: https://www. annanurse.org/download/forms/meetings/symposium/abstracts13/thomas1.pdf

15. Prezerakos $\mathrm{P}$, Galanis $\mathrm{P}$, Moisoglou I. The work environment of haemodialysis nurses and its impact on patients' outcomes. Int J Nurs Pract. 2015;21:132-40. doi: 10.1111/ijn.12223

16. Ulrich B, Kear T. Patient safety culture in nephrology nurse practice settings: initial findings. Nephrology Nurs J [Internet]. 2014 [cited 2018 Jul 10];41(5):459-75. Available from: https://www.annanurse.org/download/reference/journal/patientSafety2.pdf

17. Thomas-Hawkins C, Flynn L, Clarke SP. Relationships between registered nurse staffing, processes of nursing care, and nurse-reported patient outcomes in chronic hemodialysis units. Nephrology Nursing Journal. 2008; 35(2): 123-131. Disponível em: https://www.ncbi.nlm. nih.gov/pmc/articles/PMC2845981/

18. Erken E, Ozelsancak R, Sahin S, Yılmaz E, Torun D, Leblebici B, et al. The effect of hemodialysis on balance measurements and risk of fall. Int Urology Nephrol. 2016;48(10):1705-11. doi: 10.1007/s11255-016-1388-7

19. Peres $L A B$, Wandeur $V$, Matsuo T. Preditores de injúria renal aguda e de mortalidade em uma Unidade de Terapia Intensiva. J Bras Nefrol. 2017;37(1):38-46. doi: 10.5935/01012800.20150007

20. Silva AFS, Magalhães DM, Rocha PRS, et al. Principais complicações apresentadas durante a hemodiálise em pacientes críticos e propostas de intervenções de enfermagem. Rev Enferm C-Oeste Min. 2018;8:e2327. doi: 10.19175/recom.v7i0.2327

21. Borges PRR, Bedendo J. Fatores de risco associados à infecção de cateter provisório em pacientes sob tratamento dialítico. Texto Contexto Enferm. 2015;24(3): 680-5. doi: 10.1590/0104-07072015000670014

22. Mieiro DB, Oliveira EBC, Fonseca REP, Mininel VA, Zem-Mascarenhas SH, Machado RC. Strategies to minimize medication errors in emergency units: an integrative review. Rev Bras Enferm. 2019;72(Suppl 1):307-14. doi: 10.1590/0034-7167-2017-0658

23. Silva AFS, Magalhães DM, Rocha PRS, et al. Intervenções de enfermagem para complicações apresentadas durante a hemodiálise em pacientes críticos. Rev Enferm C-Oeste Min. 2018;8:e2327. doi: 10.19175/recom.v7i0.2327

24. Costa RHS, Dantas ALM, Leite EMD, Lira ALBC, Vitor AF, Silva, RAR. Complicações em pacientes renais durante sessões hemodialíticas e intervenções de enfermagem. Rev Pesqui Cuid Fundam 2015;7(1):2137-46. doi: 10.9789/2175-5361.2015.v7i1.2137-2146

25. Moreira FTLS, Callou RCM, Albuquerque GA, Oliveira RM. Estratégias de comunicação efetiva no gerenciamento de comportamentos destrutivos e promoção da segurança do paciente. Rev Gaúcha Enferm. 2019;40(esp):e20180308. doi: 10.1590/1983- 1447.2019.20180308.

26. Aiken LH, Sloane D, Griffiths P, Rafferty AM, Bruyneel L, McHugh M, et al. Nursing skill mix in European hospitals: cross-sectional study of the association with mortality, patient ratings, and quality of care. BMJ Qual Saf. 2017;26(7):559-68. doi: 10.1136/bmjqs-2016-005567

27. Fugulin FMT, Gaidzinski RR, Lima AFC. Dimensionamento de pessoal de enfermagem em Instituições de Saúde. In: Kurcgan TP. Gerenciamento em enfermagem. 3. ed. Rio de Janeiro: Guanabara Koogan; 2016. 116-27.

28. Silva LC, Oliveira DAL, Santos ABR. Dimensionamento de pessoal e sua interferência na qualidade do cuidado. Rev Enferm UFPE. 2019;13(1):491-8. doi: 10.5205/1981-8963-v13i02a236551p491-498-2019

29. Conselho Federal de Enfermagem (BR). Resolução № 527, de 3 de novembro de 2016. Atualiza e estabelece parâmetros para o Dimensionamento do Quadro de Profissionais de Enfermagem nos serviços/locais em que são realizadas atividades de enfermagem. [Internet]. Brasília; 2016 [cited 2018 Jul 10]. Available from: http://www.saude.campinas.sp.gov.br/lista_legislacoes/legis_2016/U_RSCOFEN-527_031116.pdf 